\title{
Effect of Pre-Harvest Application of Gibberellic Acid on Fruit Quality and Shelf Life of Mandarin (Citrus reticulata Blanco)
}

\author{
Pradeep Raj Rokaya', Dilli Ram Baral1, Durga Mani Gautam¹, Arjun Kumar Shrestha1, \\ Krishna Prasad Paudyal ${ }^{2}$ \\ ${ }^{1}$ Agriculture and Forestry University, Rampur, Chitwan, Nepal \\ ${ }^{2}$ National Agricultural Research Institute (NARI), NARC, Khumaltar, Lalitpur, Nepal \\ Email: rokayapradeep@yahoo.com
}

Received 23 February 2016; accepted 8 May 2016; published 11 May 2016

Copyright (C) 2016 by authors and Scientific Research Publishing Inc.

This work is licensed under the Creative Commons Attribution International License (CC BY). http://creativecommons.org/licenses/by/4.0/

cc) (7) Open Access

\section{Abstract}

Mandarin (Citrus reticulata Blanco) is a promising fruit crop gaining popularity for its human nutrition and economic importance in Nepal. The qualitative losses during pre-harvest stage hinder the productivity and subsequently shorten the on-tree storability. An experiment was conducted to assess the effect of gibberellic acid on quality and shelf life of the mandarin fruit. $\mathrm{GA}_{3}$ at 10,20 , and $30 \mathrm{ppm}$ as against of control were evaluated. Observations on fruit weight (g), fruit firmness $\left(\mathrm{kg} / \mathrm{cm}^{2}\right)$, rind colour (1 - 5 index), juice recovery (\%), TSS/acid ratio, PLW (\%), decay loss (\%), and ascorbic acid $(\mathrm{mg} / 100 \mathrm{ml})$ were recorded at three harvesting dates i.e. $20 \mathrm{Nov}, 5 \mathrm{Dec}$, and 20 Dec and storage condition. It has been revealed that the fruits treated with $\mathrm{GA}_{3}$ at $20 \mathrm{ppm}$ retained higher fruit weight $(128.6 \mathrm{~g})$, more firmness $\left(3.54 \mathrm{~kg} / \mathrm{cm}^{2}\right)$, better juice recovery $(57.75 \%)$, and greater TSS/acid ratio (21.24) at the end of study (20 December). The PLW was found less with $\mathrm{GA}_{3}$ at $30 \mathrm{ppm}$ in both ambient $(5.17 \%)$ and cellar $(6.69 \%)$ condition as against untreated fruits $(9.52 \%$ and $11.76 \%)$. Similarly, the decay loss was minimum in the fruits treated with $\mathrm{GA}_{3}$ at 30 ppm both with ambient $(1.02 \%)$ and cellar condition $(8.21 \%)$ as against control with ambient (5.54\%) and cellar (21.58\%).

\section{Keywords}

Fruit Quality, Gibberellic Acid, Peel Puncture Resistance, Physiological Loss in Weight, Postharvest Shelf Life 


\section{Introduction}

Mandarin (Citrus reticulata Blanco) is a promising fruit crop regarding its positive influence on human nutrition and economic importance in Nepal. Farmers in the mid hills of Nepal produce large amount of mandarin during its peak season i.e. November-December [1]. In the peak season, growers fetch lower price due to seasonal glutting, and in lean season, fruits are not available in the market. The consumers suffer due to unavailability of fruits beyond the peak harvesting and have to pay high price for cold stored coming all the way from India [2]. The fluctuation in the fruit supply and price can be minimized either by extending the harvesting period or by holding the fruits in storage [3]. Mandarin is a perishable fruit that cannot be kept on tree storage without any treatments.

Pre-harvest application of $\mathrm{GA}_{3}$ has been reported to delay softening, delay rind colour, and minimize the fruits drops and puffiness [4]-[6]. Pre-harvest spray of $\mathrm{GA}_{3}$ in mandarin delayed ripening and decay loss of fruits [7]. Kher et al. [8] found that $\mathrm{GA}_{3}$ was the most effective chemicals in increasing the weight, specific gravity and decreasing the total acid content in guava fruits. Brahmachari and Rani [9] suggested that $\mathrm{GA}_{3}$ and kinetin are beneficial in prolonging the shelf life and retaining the quality of guava fruits. Bhattacharya [10] reported that the fruits treated with $\mathrm{GA}_{3}$ extended the storage life of lime fruits over control by delaying in ripening. Maturity and colour break stage were delayed with $\mathrm{GA}_{3} 50 \mathrm{ppm}$ treatment in Satluj Purple plum [11]. There was a decrease in TA, increase in total juice volume, TSS/acid ratio, and along with delayed rind colour by $\mathrm{GA}_{3}$ [12]. In citrus fruit, $\mathrm{GA}_{3}$ application delayed the loss of chlorophyll [13]. Exogenous application of growth regulators significantly decreased fruit drop leading to increase in total number of fruits per plants, fruit weight, juice percentage, total soluble solids, acidity, and vitamin C [14]. Fruit skin colour advanced in $\mathrm{GA}_{3}$ applied trees [15]. $\mathrm{GA}_{3}$ delayed the maturity and reduced the postharvest losses in kinnow mandarin [16]. Considering perishability and market glut in peak season, this study was undertaken to minimize the pre-harvest losses and to get high price beyond peak season through increase in harvest span. Therefore, pre-harvest application of $\mathrm{GA}_{3}$ was investigated to evaluate its efficacy during on-tree storage and the consequent postharvest storage of mandarin.

\section{Materials and Methods}

This investigation was undertaken on 15 years old uniform and healthy tree with spacing of $5 \mathrm{~m} \times 5 \mathrm{~m}$ in the Lamjung district of Nepal in the year 2012 and 2013. On 16 October i.e. five weeks before normal harvesting (with fruits at colour break), tree were treated with $\mathrm{GA}_{3}(10,20$, and $30 \mathrm{ppm})$ as a whole tree spray containing Tween- 80 surfactant $(0.02 \% \mathrm{v} / \mathrm{v})$. The spray of surfactant served as control. The second spray was applied two weeks later. The experiment was laid out in randomized complete block design (RCBD) including four treatments with four replications. The fruits were harvested in November 20, December 5, and December 20 and analysis was done with the respective date of harvesting. 20 fruits in each replication were sampled for analysis. Fruit weight was taken in gram by top balance, fruit firmness in terms of peel puncture resistance by Effigy tester for citrus (model 011). The rind colour was evaluated as in index where colours were given numerical value: full green $=1$, yellowish green $=2$, greenish yellow $=3$, yellowish orange $=4$ and full orange $=5$. Total Soluble Solids in juice were determined by hand refractometer in ${ }^{0} \mathrm{Brix}$, acidity by titrating against $0.1 \mathrm{~N}$ titration and vitamin $\mathrm{C}$ as mentioned by AOAC [17]. Data were tabulated in excel and analysed by using standard procedures as proposed Gomez and Gomez [18].

\section{Results and Discussion}

\subsection{Fruit Weight}

Data presented in the Table 1 show that fruit weight was increased significantly in all the treatments of $\mathrm{GA}_{3}$ with the advancement of the maturity as compared to control. Perusal on observations of fruit weight indicates that fruits treated with $\mathrm{GA}_{3}$ was able to increase in weight. Maximum fruit weight was recorded with $\mathrm{GA}_{3}$ at 20 ppm (128.6 g) against control (95.51 g) at the end of experiment (20 December). It was noted that $\mathrm{GA}_{3}$ treated fruit had maximum increase on 5 December and beyond this date it was observed slow, stagnant and declined where as sharp decline in control fruits. Based on the findings, $\mathrm{GA}_{3}$ with the concentration at $10-20 \mathrm{ppm}$ was the most effective effect treatment for fruit growth in mandarin. The higher fruit growth with $\mathrm{GA}_{3}$ treated fruits might be due to mediating process for faster translocation and mobilization of photosynthates from source. These findings are in agreement with the reports of Singh et al. [19] in pear, and Pal et al. [20] in kinnow man- 
Table 1. Periodical changes on fruit weight, rind colour, and peel puncture resistance in mandarin fruit during on-tree storage in 2012 and 2013.

\begin{tabular}{cccccccccc}
\hline \multirow{2}{*}{ Treatments (ppm) } & \multicolumn{3}{c}{ Fruit weight (gram) } & \multicolumn{3}{c}{ Rind colour index $(1-5$ scale $)$} & \multicolumn{4}{c}{ Peel puncture resistance $\left(\mathrm{kg} / \mathrm{cm}^{2}\right)$} \\
\cline { 2 - 10 } & A & B & C & A & B & C & A & B & C \\
\hline GA $_{3} 10$ & 110.58 & 125.04 & 125.01 & 2.05 & 2.93 & 3.42 & 4.36 & 4.21 & 3.24 \\
GA $_{3} 20$ & 113.50 & 127.46 & 128.60 & 1.92 & 2.84 & 3.16 & 4.19 & 3.80 & 3.54 \\
GA $_{3} 30$ & 113.16 & 123.80 & 124.66 & 1.83 & 2.69 & 2.97 & 4.19 & 3.71 & 3.45 \\
Control & 98.75 & 98.26 & 95.51 & 3.37 & 4.63 & 5.00 & 3.75 & 2.80 & 2.73 \\
LSD (0.05) & 6.07 & 9.36 & 7.88 & 0.26 & 0.39 & 0.40 & NS & 0.27 & NS \\
\hline
\end{tabular}

$\mathrm{A}=20.11, \mathrm{~B}=05.12$, and $\mathrm{C}=20.12$.

darin who had observed $\mathrm{GA}_{3}(10 \mathrm{ppm})$ has resulted in an increase in fruit diameter and Kumar et al. [21] in the fruit of strawberry who stated that gibberellic acid at $12.5 \mathrm{ppm}$ resulted in the highest fruit length, breadth, and weight. Kaur et al. [11] has also reported that $\mathrm{GA}_{3}$ at 25 and $50 \mathrm{ppm}$ increased the fruit weight in plum and inconsonance with the observation of Bose et al. [22] who recorded three times increment on fruit weight in mandarin. The increment in fruit weight might be due to hormone directed to transportation and accumulation of phytosynthates which resulted in better fruit development and also acceleration of cell division, elongation, and enlargement. Similar observation was recorded by Daulta and Veniwal [23] in sweet orange who claimed maximum weight with $\mathrm{GA}_{3}$ sprayed tree fruits.

\subsection{Rind Colour}

Rind colour is the perhaps most important and reliable index of mandarin fruit. $\mathrm{GA}_{3}$ treated fruits resulted in delaying the rind colour development as well delay in the maturity of the mandarin fruits. Perusal from the observations in the Table 1 shows that $\mathrm{GA}_{3}$ treated fruits resulted in significant delay in the rind colour development. On 20 November, the index value of 3.37 indicated orange colour in control as against index of less than 2.0 indicating greener fruits with $\mathrm{GA}_{3}$ treatments. Likewise at the end of the study (20 December), the colour index of $\mathrm{GA}_{3}$ treated fruits was 2 - 3.5 indicating orange colour as against of 5.0 indicating orange yellow with over ripe fruits in control. These findings are in consonance with the findings of the Ladaniya [5] in mandarin who stated that $\mathrm{GA}_{3}$ treatments significantly delayed the rind colour development in Nagpur mandarin. Kaur et al. [11] also observed that colour development of the fruits was delayed by gibberellin treatments in plum. Gibberellin has been reported to delay chlorophyll degradation and the senescence in the fruits [24]. Colour development is associated with a loss of texture, increasing sugar content and decreasing acidity [25].

\subsection{Peel Puncture Resistance}

Peel puncture resistance serves as fruit quality determinant. Peel puncture resistance was significantly higher in the $\mathrm{GA}_{3}$ treated fruits as compared to control. Table 1 shows that on 20 November harvesting, the firmness of the fruits was non-significant although $\mathrm{GA}_{3}$ treated fruits had appeared higher index value $\left(>4.0 \mathrm{~kg} / \mathrm{cm}^{2}\right)$ than control $\left(3.75 \mathrm{~kg} / \mathrm{cm}^{2}\right)$. On 5 December, this value was decreased in all treatments, however, $\mathrm{GA}_{3}$ treated fruits had significantly much higher $\left(3.71-4.21 \mathrm{~kg} / \mathrm{cm}^{2}\right)$ than control $\left(2.8 \mathrm{~kg} / \mathrm{cm}^{2}\right)$. On 20 December, the resistance sharply declined and observed as non-significant among the treatments. However, fruits treated with $\mathrm{GA}_{3}$ at 20 ppm had higher firmness $\left(3.54 \mathrm{~kg} / \mathrm{cm}^{2}\right)$ than the untreated fruits $\left(2.73 \mathrm{~kg} / \mathrm{cm}^{2}\right)$. These results are in conformity with the findings of the Ladaniya [5] in Nagpur mandarin who stated that $\mathrm{GA}_{3}$ treated fruits had higher peel puncture resistance and Kaur et al. [11] observed the similar trends in the plum. In all the treatments the firmness was found decreasing with ripening advancement. This might be due to cell wall loosening of the fruit. The pro-pectin, which acts as a cementing material for binding the cellulose and hemicelluloses is converted to soluble pectin. As a result it loosens the cell wall's binding force during ripening [25]. Bakhshi and Chadha [13] claimed that in citrus, $\mathrm{GA}_{3}$ application given to fruits delayed the loss of chlorophyll in limes and lemons.

\subsection{Juice Recovery}

Perusal on data as indicated in Table 2 shows that the juice recovery percentage was significantly higher in 
Table 2. Periodical changes on juice recovery, TSS/acid ratio, and Vitamin C in mandarin Vitamin C of GA 3 treated mandarin fruit during on-tree storage in 2012 and 2013.

\begin{tabular}{cccccccccccc}
\hline & \multicolumn{3}{c}{ Juice recovery (\%) } & \multicolumn{3}{c}{ TSS/acid ratio } & \multicolumn{4}{c}{ Vitamin C (mg/100ml) } \\
\cline { 2 - 11 } Treatments (ppm) & A & B & C & A & B & C & A & B & C \\
\hline $\mathrm{GA}_{3} 10$ & 52.68 & 55.08 & 55.68 & 11.86 & 15.00 & 20.04 & 31.03 & 27.5 & 24.75 \\
$\mathrm{GA}_{3} 20$ & 53.72 & 56.23 & 57.75 & 12.35 & 15.48 & 21.24 & 30.49 & 27.14 & 24.75 \\
$\mathrm{GA}_{3} 30$ & 53.80 & 54.85 & 55.21 & 12.16 & 15.83 & 17.77 & 29.86 & 28.52 & 23.17 \\
Control & 48.90 & 47.11 & 45.06 & 12.66 & 15.99 & 17.83 & 28.71 & 25.97 & 21.95 \\
LSD (0.05) & NS & NS & 6.77 & NS & NS & 2.53 & NS & NS & NS \\
\hline
\end{tabular}

$A=20.11, B=05.12$, and $C=20.12$.

fruits treated $\mathrm{GA}_{3}$ than non-treated fruits. At normal harvesting date (20 November), the juice percentage was non-significant but higher juice was obtained from the fruit treated with $\mathrm{GA}_{3}$. On later stage i.e. 20 December the juice percentage was recorded highly significant (57.75\%) in the fruits treated with $\mathrm{GA}_{3}$ at $20 \mathrm{ppm}$ as against of control (45.06\%) because $\mathrm{GA}_{3}$ treated fruits remained firm and non-treated fruits were overripe in their condition. Similar observations were recorded by Haribabu et al. [26] in kagzi lime, Bhat et al. [27] in lemon and Daulta and Veniwal [23] in sweet orange who have reported that $\mathrm{GA}_{3}$ treatments increased the percentage of juice. Increased in juice percentage may also be explained by the fact that hormones play a regulating role in the mobilization of metabolites within a plant and it is well established fact that developing fruits are extremely active metabolic "sinks" which mobilize metabolites and direct their flow from vegetative structure.

\subsection{TSS/Acid Ratio}

Perusal on data as indicated in Table 2 shows that the TSS/acid ratio was not significant on 20 November and 5 December in all the treatments. However, non-treated fruits recorded higher TSS/acid ratio (12.66) than $\mathrm{GA}_{3}$ treated fruits $\left(11.86\right.$ - 12.16). The TSS/acid ratio was significantly higher in the $\mathrm{GA}_{3}$ treated fruits $(17.77$ - 21.24) against to control (17.83). $\mathrm{GA}_{3}$ at $20 \mathrm{ppm}$ showed the highest TSS/acid ratio (21.24) followed by $\mathrm{GA}_{3}$ at $10 \mathrm{ppm}$ at the end of the study i.e. on 20 December whereas the lowest ratio was observed in control (17.83). These findings substantiate the earlier reports of Singh et al. [19] in pear and Kaur et al. [11] in plum and Ladaniya [5] in Nagpur mandarin who reported increase in TSS/acid ratio with $\mathrm{GA}_{3}$ treatments. It was obvious that the TSS content increased while juice acidity decreased resulting in an increase in the TSS/acid ratio during holding of fruit on the tree. The increased TSS content could have been due to further synthesis and accumulation of photosynthates in the fruits on the tree [28]. The loss in acidity was reported to be due to normal respiration and conversion to other metabolities and loss was similar for fruit stored on the tree or in cold room [24].

\subsection{Vitamin C Content}

Higher vitamin C content imparts higher nutritive value to fruits. Data in Table 2 shows that the vitamin C content decreased with the advancement of storage of fruits on tree in all treatments. However, more pronounced decrease was found in the non-treated fruits. A decrease in ascorbic acid could be due to enzymatic loss of L-ascorbic acid where it is converted to 2-3-dioxy-L-gluconic acid [29]. Vitamin C content in the $\mathrm{GA}_{3}$ treated and non-treated fruit was non-significant during the study (20 November to 20 December). However, the content of vitamin $\mathrm{C}$ was recorded higher in the $\mathrm{GA}_{3}$ treated fruits than in non-treated. The maximum vitamin $\mathrm{C}$ content was obtained with $\mathrm{GA}_{3}$ at10 $(24.75 \mathrm{mg} / 100 \mathrm{ml})$ and $20 \mathrm{ppm}(24.75 \mathrm{mg} / 100 \mathrm{ml})$ followed by $\mathrm{GA}_{3}$ at $30 \mathrm{ppm}$ (23.17 mg/100) as against control $(21.95 \mathrm{mg} / 100 \mathrm{ml})$. These results were in line with the findings of Sindhu and Sighrot [30] who reported maximum ascorbic acid content in $\mathrm{GA}_{3}$ treated fruits.

\subsection{Physiological Loss in Weight (PLW)}

The perusal in Table 3, indicated the increase in PLW with the increase in storage period both at ambient and under cellar condition. The PLW was found significant among the treatments. The minimum loss in weight was 
Table 3. Effect of $\mathrm{GA}_{3}$ on weight loss and decay loss of mandarin fruit during storage at ambient for 15 days $\left(14^{\circ} \mathrm{C}-18^{\circ} \mathrm{C}\right.$ and $45 \%-73 \% \mathrm{RH})$ and cellar condition for 90 days $\left(10^{\circ} \mathrm{C}-12^{\circ} \mathrm{C}\right.$ and $\left.85 \%-90 \% \mathrm{RH}\right)$.

\begin{tabular}{|c|c|c|c|c|}
\hline \multirow{2}{*}{ Treatments (ppm) } & \multicolumn{2}{|c|}{ Ambient } & \multicolumn{2}{|c|}{ Cellar } \\
\hline & Weight loss (\%) & Decay loss (\%) & Weight loss (\%) & Decay loss (\%) \\
\hline $\mathrm{GA}_{3} 10$ & 6.01 & 2.12 & 8.24 & 13.24 \\
\hline $\mathrm{GA}_{3} 20$ & 5.61 & 1.18 & 6.77 & 10.27 \\
\hline $\mathrm{GA}_{3} 30$ & 5.17 & 1.02 & 6.69 & 8.21 \\
\hline Control & 9.52 & 5.54 & 11.76 & 21.58 \\
\hline LSD (0.05) & 0.59 & NS & 1.63 & 3.78 \\
\hline
\end{tabular}

observed in the fruits treated with $\mathrm{GA}_{3}$ at $30 \mathrm{ppm}$ (5.17\%) followed by $\mathrm{GA}_{3}$ at $20 \mathrm{ppm}(5.61 \%)$, and $\mathrm{GA}_{3}$ at 10 ppm (6.01\%) and maximum loss in weight was recorded in control (9.52\%) stored at ambient condition for 15 days. Under the cellar condition, the maximum PLW was recorded with the fruit treated with $\mathrm{GA}_{3}$ at $30 \mathrm{ppm}$ (6.69\%) followed by $\mathrm{GA}_{3}$ at $20 \mathrm{ppm}$ (6.77\%), and $\mathrm{GA}_{3}$ at $10 \mathrm{ppm}(824 \%)$ as against control (11.76\%) at the end of the 90 days. The possible reason for reduction in weight loss by $\mathrm{GA}_{3}$ could be due to its ability to retain more water against force of evaporation. $\mathrm{GA}_{3}$ acts an antisenescent and antirespirant, which inhibited catabolic activities and consequently reduced the weight loss during storage [9]. These findings are conformity with the reports of Sindhu and Singhrot [30] in lemon, (Brahmachari and Rani [9] in guava, Ladaniya [5] in Nagpur mandarin, and Ahlawat et al. [30] in kinnow mandarin who reported decrease in weight loss of fruits during storage.

\subsection{Decay Loss}

Table 3 shows that the decay loss increased with the increase in period of storage in all the treatments. The decay loss among the treatments was not significant at ambient condition. However, the minimum decay loss was found in the fruits with $\mathrm{GA}_{3} 30$ at ppm (1.02\%) followed by $\mathrm{GA}_{3}$ at $20 \mathrm{ppm}(1.18 \%)$ and $\mathrm{GA}_{3}$ at $10 \mathrm{ppm} \mathrm{(2.12 \% )}$ as against control (5.54\%). On the other hand, the minimum decay loss was observed in the fruits treated with $\mathrm{GA}_{3}$ at $30 \mathrm{ppm}$ (8.21\%).The lesser decay loss percentage in $\mathrm{GA}_{3}$ treated fruits could be due to antisenesecent and antirespirant properties of the gibberellins which prevent the cellar disintegration with enhancing resistant ability in the fruit. Similar results were reported by Brahmachari and Rani [9] in guava, Sindhu and Singhrot [30] in lemon, Ladaniya [5] in Nagpur mandarin and Ahlawat et al. [31] in kinnow mandarin.

\section{Conclusion}

On the basis of the above experimental findings, we concluded that $\mathrm{GA}_{3}$ at 20 ppm was more effective to increase fruit weight and overall fruit quality whereas $\mathrm{GA}_{3}$ at $30 \mathrm{ppm}$ was the best for the prolonging the shelf life and minimising the physiological loss in weight (PLW) and decay loss of mandarin in both ambient and cellar condition. $\mathrm{GA}_{3}$ at $20 \mathrm{ppm}$ retained higher fruit weight (128.6 g), higher peel puncture resistance $\left(3.54 \mathrm{~kg} / \mathrm{cm}^{2}\right)$, higher juice recovery (57.75\%), and higher TSS/acid ratio (21.24) during the storage. In overall, $\mathrm{GA}_{3}$ was proved to delay the ripening of the fruits for one month through delaying the chlorophyll development and reducing the loss of texture, decreasing sugar content and increasing acidity.

\section{Acknowledgements}

The authors are thankful to Director General of Department of Food Technology and Quality Control (DFTQC) of Ministry of Agricultural Development, and the chief of postharvest research unit of NARC, Khumaltar, Lalitpur for providing laboratory facility during the experiment.

\section{References}

[1] Subedi, P.P. (2001) Postharvest and Market Assessment of Citrus Fruits. In: Subedi, P.P., Dhakal, D.D. and Khanal, N.P., Eds., Integrated Management for Citrus Decline, Workshop, Damauli, 46-50.

[2] Gautam, D. and Adhikari, R.R. (1989) Study on Modified Local Methods of Orange Storage. Journal of the Institute of 
Agriculture and Animal Science, 10, 91-95.

[3] Bastakoti, P. and Gautam, D.M. (2007) Effect of Maturity Stages and Postharvest Treatments on Shelf Life and Quality of Mandarin Oranges in Modified Cellar Store. Journal of Institute of Agriculture and Animal Science, 28, 65-74.

[4] Kawase, K., Susuki, K. and Hirose, K. (1981) Use of Growth Regulators to Control Rind Puffing of Satsuma Mandarin Fruit. Proceedings of International Society of Citriculture, 1, 237-239.

[5] Ladaniya, M.S. (1997) Response of Nagpur Mandarin Fruit to Preharvest Sprays of GA3 and Carbendazim. Indian Journal of Horticulture, 54, 205-212.

[6] Ladaniya, M.S. (2001) Post-Harvest Technology of Fresh Citrus Fruits. In: Singh, S. and Naqvi, S.A.M.H., Eds., Citrus, International Book Distributing Co., Lakhnow, 459-473.

[7] Chapman, J.C., Book, G. and Peacook, B.C. (1979) Effect of Pre-Harvest GA Sprays. Ellendale Mandarin Fruits. Queensland Journal of Agriculture and Animal Science, 36, 53.

[8] Kher, R., Bhat, S. and Wali, V.K. (2005) Effect of Foliar Application of GA3, NAA and CCC on Physic-Chemical Characteristics of Guava CV. Sardar. Haryana Journal of Horticultural Sciences, 34, 31-32.

[9] Brahmachari, V.S. and Rani, R. (2005) Shelf Life Extension in Guava with Pre-Harvest Spray of Certain Growth Substances and Polyethylene Wrapping. Haryana Journal of Horticulture Science, 34, 36-38.

[10] Bhattacharya, S.C. (1991) Storage Studies in Lime (Citrus aurantifolia). Master Thesis, Bidhan Chandra Krishi Vishowvidhaylaya, West Bengal, 27-26.

[11] Kaur, H., Singh, A., Gupta, M. and Randhawa, J.S. (2008) Effect of NAA and Gibberellic Acid on Pre-Harvest Fruit Drop and Quality of Satluj Purple Plum. Haryana Journal of Horticultural Sciences, 37, 31-32.

[12] Thapa, B.B. and Gautam, D.M. (2002) Pre-Harvest Application of Gibberellic Acid and Maturity Stage on Fruit Quality and Shelf Life of Mandarin. Journal of the Institute of Agriculture and Animal Science, 23, 41-47.

[13] Bakhshi, J.S. and Chadha, K.L. (1968) Gibberellins and Plant Growth-A Review. The Panjab Horticultural Journal, 8, 78-113.

[14] Nawaz, M.A., Ahmad, W., Ahamad, S. and Khan, M. (2008) Role of Growth Regulators in Pre-Harvest Fruit Drop, Yield and Quality in Kinnow Mandarin. Pakistan Journal of Botany, 40, 1971-1981.

[15] Sen, A., Meyvaci, K.B., Can, H.Z. and Teksur, P.K. (2012) Effect of Preharvest Gibberellic and Calcium Applications On-Tree Storage of Satsuma Mandarins. Proceedings of the VII International Postharvest Symposium, 25-29 June 2012, 233-239. http://www.actahort.org/books/1012/1012 26

[16] Amir, M., Chaturvedi, O.P. and Tripathi, V.K. (2003) Effect of Pre-Harvest Application of Gebberellic Acid and Calcium Nitrate on the Fruit Maturity and Storage Quality of Kinnow Mandarin. Farm Science Journal, 12, 148-149.

[17] AOAC (1995) Official Methods of Analysis. 16th Edition, Association of Official Analytical Chemists, Washington DC.

[18] Gomez, A.K. and Gomez, A.A. (1984) Statistical Procedures for Agricultural Research. John Wiley and Sons Inc., New York.

[19] Singh, A. K., Singh, R. and Mann, S.S. (2003) Effect of Plant Regulators and Nutrients on Fruit Set, Yield and Quality of Pear CV. Le-Conte. Indian Journal of Horticulture, 60, 34-39.

[20] Pal, R.N., Singh, R., Vij, Y.K. and Munshi, S.K. (1977) Effect of 2, 4-D, GA3 and Cycocel, and Fruit Growth Pattern of Kinnow Mandarin. Indian Journal of Horticulture, 34, 4-7.

[21] Kumar, J., Rana, S.S., Verma, H.S. and Jindal, K.K. (1996) Effect of Various Growth Regulators on Growth, Yield and Fruit Quality of Strawberry CV. Tioga. Haryana Journal of Horticultural Sciences, 25, 168-171.

[22] Bose, T.K., Hussain, T., Mitra, S.K. and Roy, A. (1988) Control of Pre-Mature Fruit Drop in Mandarin Orange. Haryana Journal of Horticultural Sciences, 17, 140-143.

[23] Daulta, B.S. and Beniwal, V.S. (1983) Effect of Time of Application, Chemicals and Concentration of Plant Growth Regulators on Composition of Fruit in Sweet Orange (Citrus sinensis Obseck) CV. Campbell Valencia. Haryana Journal of Horticultural Sciences, 12, 168-172.

[24] EI-Otmani, M. and Coggins Jr., C.W. (1991) Growth Regulator Effect on Retention of Quality of Stored Citrus Fruits. Scientia Horticulturae, 45, 261-272. http://dx.doi.org/10.1016/0304-4238(91)90072-7

[25] Rana, M.K. (2006) Ripening Changes in Fruits and Vegetables-A Review. Haryana Journal of Horticultural Sciences, 35, 271-279.

[26] Sri Hari Babu, R., Rajput, C.B.S. and Rath, S. (1982) Effect of Zinc, 2, 4-D and GA3 in Kagzi Lime (Citrus aurantifolia Swingle) IV Fruit Quality. Haryana Journal of Horticultural Sciences, 11, 59-65.

[27] Bhat, A., Kher, R. and Gupta, S.P. (2006) Effect of Growth Regulators and Nutrients on Fruit Cracking and Fruit Quality in Lemon. Haryana Journal of Horticulture Science, 35, 267. 
[28] Murata, T. (1977) Studies on the Postharvest Physiology and Storage of Citrus Fruit VIII. Metabolism of Citrate- ${ }^{14} \mathrm{C}$ and Glucose- ${ }^{14} \mathrm{C}$ in Satsuma Mandarin Fruit during Storage. Journal of the Japanese Society for Horticultural Science, 46, 375-379. http://dx.doi.org/10.2503/jishs.46.375

[29] Mapson, L.W. (1970) The Bio-Chemistry of Fruits and Their Products. In: Hulme, A.C., Ed., Vitamins in Fruits, Vol. 1, Academic Press, London, 369-384.

[30] Sindhu, S.S. and Singhrot, R.S. (1993) Effect of Pre-Harvest Spray of Growth Regulator and Fungicides on the Shelf Life of Lemon CV. Baramasi. Haryana Journal of Horticulture Science, 22, 204-206.

[31] Alhawat, V.P., Daulta, B.S. and Singh, J.P. (1984) Effect of Pre-Harvest Application of GA3 and Captan on Storage Behaviour of Kinnow-A Mandarin Hybrid. Haryana Journal of Horticulture Science, 13, 4-8. 